\title{
Aktivitas Insektisida Campuran Minyak Mimba (Azadirachta indica) dan Minyak Jarak Kepyar (Ricinus communis) terhadap Spodoptera frugiperda
}

\author{
Retno Wulansari ${ }^{1}$, Yusup Hidayat ${ }^{2}$, dan Danar Dono ${ }^{2 *}$ \\ ${ }^{1}$ Program Studi Magister Agronomi Konsentrasi Hama dan Penyakit Tumbuhan, \\ Fakultas Pertanian, Universitas Padjadjaran \\ ${ }^{2}$ Departemen Hama dan Penyakit Tumbuhan, Fakultas Pertanian Universitas Padjadjaran, \\ Jl. Raya Bandung Sumedang KM 21, Jatinangor, 45363 \\ *Alamat korespondensi: danar.dono@unpad.ac.id
}

\begin{tabular}{|c|c|}
\hline INFO ARTIKEL & ABSTRACT/ABSTRAK \\
\hline Diterima: $\quad 20-07-2021$ & \\
\hline $\begin{array}{lr}\text { Direvisi: } & 06-22-2021 \\
\text { Dipublikasi: } 23-01-2022\end{array}$ & $\begin{array}{l}\text { Insecticide Activity Mixture Neem Oil (Azadirachta indica) and Castor Oil } \\
\text { (Ricinus communis) Against Spodoptera Frugiperda }\end{array}$ \\
\hline
\end{tabular}

Keywords:

Botanical insecticide,

Developmental

disruption, Joint

action, Reproduction,

Synergistic

Kata Kunci:

Gangguan

perkembangan,

Insektisida nabati,

Joint action,

Sinergistik, Reproduksi
Spodoptera frugiperda is invasive pest that cause crop failure in maize. Alternative control is being develop against $S$. frugiperda with botanical insecticides. The aim of this study was to determine synergistic activity of mixture botanical insecticides oil of Azadirachta indica and Ricinus communis. The experimental design used was randomized block design consisting of oils of $A$. indica, $R$. communis and their mixture with five levels of concentrations and one control which were repeated four times. The test used residual feed method on larvae instar II for 48 hours, then the treated leaves were replaced with untreated leaves to feed the larvae until they developed into pupae. The relationship between concentration and mortality of tested insects was analyzed used probit analysis, while other parametres were analysed using analysis of variance. The results showed that $A$. indica, $R$. communis and their oils mixture were toxic to $S$. frugiperda larvae. Activity of $A$. indica and $R$. communis oil mixture showed that at the level of LC50 on 2-8 days after treatment (DAT) was antagonistic, the mixture at 10 DAT was additive, and at 12-18 DAT was weakly synergistic, while at the level of LC95 on 2-8 DAT was antagonistic, and 10-18 DAT was strong synergistic. Furthermore, the mixture can cause developmental inhibition, decrease the fecundity and fertility, and decrease the lifespan male and female adults. Thus, the oil mixture of $A$. indica and $R$. communis was potential to be developed as alternative insecticide to control $S$. frugiperda.

Spodoptera frugiperda merupakan hama invasif yang menyebabkan kegagalan panen pada tanaman jagung. Salah satu alternatif pengendalian ramah lingkungan yang terus dikembangkan terhadap $S$. frugiperda yaitu pengendalian dengan insektisida nabati. Penelitian ini bertujuan untuk mengetahui aktivitas sinergis campuran insektisida nabati minyak $A$. indica dan $R$. communis. Desain percobaan menggunakan Rancangan Acak Kelompok terdiri dari minyak $A$. indica, $R$. communis, serta campurannya dengan lima taraf konsentrasi dan satu kontrol yang diulang empat kali. Pengujian menggunakan metode residu pakan pada larva instar II selama 48 jam, selanjutnya daun perlakuan diganti dengan pakan tanpa perlakuan hingga larva berkembang menjadi pupa. Hubungan konsentrasi minyak nabati dengan kematian serangga uji dianalisis menggunakan analisis probit, sedangkan peubah lainnya dianalisis dengan sidik ragam. Hasil penelitian menunjukkan 
minyak $A$. indica, $R$. communis, serta campurannya bersifat toksik terhadap larva $S$. frugiperda. Aktivitas campuran minyak $A$. indica dan $R$. communis pada taraf LC50 waktu pengamatan 2-8 hari setelah perlakuan (HSP) bersifat antagonistic, pada 10 HSP bersifat aditif, dan pada 12-18 HSP bersifat sinergistik lemah, sementara pada taraf LC95 waktu pengamatan 2-8 HSP bersifat antagonistic dan pada 10-18 HSP bersifat sinergistik kuat. Selain itu, minyak nabati tersebut memiliki aktivitas penghambatan perkembangan, penurunan fekunditas dan fertilitas, serta penurunan umur imago jantan dan betina $S$. frugiperda. Dengan demikian, campuran minyak nabati $A$. indica dan $R$. communis berpotensi dikembangkan sebagai insektisida alternatif pengendalian $S$. frugiperda.

\section{PENDAHULUAN}

Spodoptera

frugiperda

(J.E.Smith)

(Lepidoptera:Noctuidae) merupakan hama tanaman jagung yang berasal dari daerah tropis dan subtropis benua Amerika. Hama ini dilaporkan pada tahun 2016 telah menyebar ke berbagai wilayah di dunia, seperti Afrika Barat dan Afrika Tengah (Goergen et al., 2016). Pada tahun 2019 S. frugiperda dilaporkan telah menyerang tanaman jagung di Indonesia di Lampung Tengah dan Lampung Timur (Lampung) (Trisyono dkk., 2019), serta Bandung, Garut, dan Sumedang (Jawa Barat) (Maharani dkk., 2019).

Larva $S$. frugiperda menyebabkan kerusakan pada titik tumbuh tanaman yang menyebabkan gagalnya pembentukan daun muda tanaman hingga mematikan tanaman jagung. Sementara itu, larva $S$. frugiperda selain merusak daun juga hanya menyisakan tulang daun dan batang tanaman. Trisyono dkk. (2019) melaporkan bahwa $S$. frugiperda menyerang tanaman jagung dari fase vegetatif hingga generatif yang dapat menyebabkan penurunan produksi. Kerusakan tongkol jagung akibat $S$. frugiperda dapat menyebabkan infeksi jamur, dan alfatoksin, serta berkurangnya kualitas biji (FAO, 2018). Oleh karena itu upaya pengendalian $S$. frugiperda harus segera dikendalikan untuk meminimalkan kerugian yang akan diakibatkan.

Upaya pengendalian $S$ frugiperda menggunakan insektisida sintetik merupakan kegiataan yang umum dilakukan untuk menekan penyebaran secara cepat dan meminimalkan kerusakan. Rwomushana et al. (2018) melaporkan bahwa insektisida yang digunakan di Afrika meliputi lamda sihalotrin, sipermetrin, etil klorpirifos, emamektin benzoat, etil palmitat, monokrotofos, dan malation. Meskipun insektisida sintetik memainkan peranan penting dalam manajemen pengendalian $S$ frugiperda, namun jika penggunaannya kurang bijaksana dapat menimbulkan efek samping yaitu berdampak buruk terhadap lingkungan, meliputi residu pestisida, matinya musuh alami, serangga penyerbuk, dan resistensi.

Resistensi insektisida sintetis pada $S$. frugiperda di luar negeri telah banyak dilaporkan (Sisay et al., 2019; Boaventura et al., 2020). Di Indonesia sendiri walaupun pengendalian yang dilakukan menggunakan insektisida sintetik, laporan mengenai terjadinya resistensi masih belum ada. Alternatif pengendalian yang ramah lingkungan saat ini terus dieksplorasi dan dikembangkan, yaitu pengendalian dengan insektisida nabati. Seperti yang dilaporkan Alves et al. (2014) bahwa metode alternatif yang menjanjikan untuk mengendalikan hama seperti $S$. frugiperda adalah penggunaan metabolit sekunder tanaman.

Salah satu jenis tumbuhan yang berpotensi digunakan sebagai insektisida nabati ialah mimba, Azadirachta indica A. Juss. (Meliaceae). Minyak $A$. indica memiliki mekanisme kerja sebagai antifeedant, penghambat pertumbuhan, dan gangguan reproduksi pada $D$. melanogaster (Bendjazia et al., 2016) dan $S$. frugiperda (Duarte et al., 2019). Selain itu, tanaman yang berpotensi dimanfaatkan sebagai sumber insektisida nabati ialah jarak, Ricinus communis L. (Euphorbiaceae). Minyak $R$. communis dilaporkan menyebabkan mortalitas dan hambatan perkembangan pada larva S. frugiperda (Dono dkk., 2020).

Insektisida nabati dapat digunakan secara tunggal maupun campuran. Potensi sinergis dari aktivitas insektisida nabati dalam bentuk campuran memiliki efek yang lebih baik terhadap hama sasaran, di antaranya dapat menurunkan dosisi aplikasi insektisida, serta membuat hama sulit untuk mengembangkan resistensi (Russianzi \& Prijono, 
2019). Efek sinergis dari minyak nabati telah banyak diteliti, di antaranya pada Piper aduncum dan Tephrosia vogelii, serta Piper retrofractrum dan Tagetes erecta (Susanto \& Prijono, 2015; Nuryanti et al., 2018). Namun, saat ini belum ada informasi terkait efek campuran dari kombinasi minyak $A$. indica dan $R$. communis, sehingga penelitian ini dilakukan untuk mengetahui aktivitas sinergisme campuran insektisida nabati minyak $A$. indica dan $R$. communis terhadap $S$. frugiperda.

\section{BAHAN DAN METODE}

\section{Waktu dan Lokasi}

Penelitian dilaksanakan pada bulan Juli sampai Desember 2020 di Laboratorium Pestisida dan Toksikologi Lingkungan, Departemen Hama dan Penyakit Tumbuhan, Fakultas Pertanian, Universitas Padjadjaran, serta rumah kaca untuk pemeliharaan tanaman.

\section{Persiapan Serangga dan Tanaman Uji}

Larva $S$. frugiperda diperoleh dari pertanaman jagung di Jatinangor, Sumedang, Jawa Barat. Selanjutnya larva $S$. frugiperda dipelihara dalam kotak plastik berukuran $34 \times 28 \times 7 \mathrm{~cm}$ yang diberi makan jagung semi. Menjelang berpupa, larva dipindahkan ke dalam kotak plastik dengan dialasi kertas hisap dan diberi serbuk gergaji sebagai medium berpupa. Pupa yang sudah terbentuk dipindahkan ke dalam kurungan tempat pemeliharaan imago berukuran 44,5 × 44,5 × 49,5 cm hingga menjadi imago.

Imago diberi makan cairan madu 10\% dalam air yang diserapkan pada segumpal kapas. Daun jagung bebas pestisida dimasukkan ke dalam botol berisi air dan diletakkan dalam kurungan plastik sebagai tempat peletakan telur. Kelompok telur yang diletakkan imago pada daun jagung tersebut dikumpulkan setiap hari dan ditempatkan dalam kotak plastik berventilasi berukuran $10 \times 9 \times 4,5$ $\mathrm{cm}$ yang dialasi kertas hisap pada bagian dasarnya. Pemeliharaan serangga dilakukan secara berkala agar ketersediaan larva pada saat pengujian tetap terjaga.

Pakan serangga uji (larva) menggunakan daun jagung bagian helai daun ketiga dan keempat dari pucuk tanaman jagung yang berumur 6 minggu. Tanaman jagung yang ditanam menggunakan benih jagung manis F1 Hibrida Talenta, PT. Agri Makmur.

\section{Penyediaan Minyak Nabati dan Pembuatan Larutan} Uji

Minyak yang digunakan terdiri dari minyak $A$. indica dan $R$. communis. Biji mimba diperoleh dari Situbondo, Jawa Timur yang dipanen bulan Februari 2019 yang selanjutnya pengolahan dilakukan di Puspromit (Pusat Studi Pengembangan Produk dan Kemitraan) Departemen Hama dan Penyakit Tumbuhan, Fakultas Pertanian, Universitas Padjadjaran. Pengolahan mimba menggunakan teknik pressing dengan pemanasan, kemudian minyak disaring dari ampas untuk memperoleh minyak mimba murni, sedangkan untuk minyak jarak diperoleh dari toko distributor bahan kimia (Brataco Chemika) di Bandung, yang dipasarkan secara komersil.

Pengujian terdiri dari minyak $A$. indica, minyak $R$. communis, serta campurannya dan kontrol. Campuran minyak nabati dibuat dengan mencampurkan minyak dengan rasio 1:1. Sebagai pelarut pengencer digunakan akuades yang mengandung 1\% (10 ml/l) campuran Tween 80 dan Span 80 (4:1). Selanjutnya pembuatan larutan minyak nabati dilakukan dengan pengambilan minyak nabati sesuai konsentrasi yang telah ditentukan menggunakan mikropipet ke dalam beaker glass $100 \mathrm{ml}$ kemudian ditambahkan akuades yang mengandung pengemulsi secara bertahap sambil diaduk lalu dimasukkan dalam labu ukur hingga volume mencapai $100 \mathrm{ml}$. Pada perlakuan kontrol digunakan larutan akuades dan pengemulsi tanpa minyak nabati.

\section{Metode Pengujian}

\section{Uji Toksisitas Tunggal dan Campuran Minyak Nabati}

Pengujian menggunakan metode residu daun pakan yang terdiri atas uji pendahuluan dan uji lanjutan. Uji pendahuluan dilakukan pada beberapa konsentrasi untuk menentukan dua taraf konsentrasi yang dapat menyebabkan mortalitas larva serangga uji dari 5\%-95\%. Selanjutnya pengujian lanjutan dilakukan menggunakan lima taraf konsentrasi dan kontrol. Pengujian lanjutan didasarkan pada uji pendahuluan, metode yang digunakan yaitu analisis kerja bersama dengan pengujian tunggal minyak $A$. indica dengan konsentrasi 0,003\%, 0,009\%, 0,030\%, 0,095\%, dan 0,300\% dan tunggal $R$. communis dengan konsentrasi 0,010\%, 0,037\%, 0,134\%, $0,491 \%, 1,800 \%$, serta pengujian campuran minyak $A$. indica dan $R$. communis (1:1) dengan konsentrasi 0,002\%, 0,007\%, 0,022\%, 0,075\%, dan 0,250\%. 
Pengujian dilakukan dengan memotong daun jagung dengan ukuran $4 \times 4 \mathrm{~cm}$ kemudian dicelupkan ke dalam masing-masing konsentrasi yang telah ditentukan selama 20 detik sehingga campuran membasahi kedua sisi permukaan secara merata, selanjutnya dikering udarakan di atas kertas tisu. Daun jagung yang telah dikering udarakan sebanyak 2 potong dimasukkan ke dalam cawan petri (diameter $9 \mathrm{~cm}$, tinggi $1,5 \mathrm{~cm}$ ) yang telah dialasi kertas tisu. Kemudian dimasukkan sepuluh larva instar II. Pengujian dilakukan dengan empat ulangan. Larva kontrol diberi pakan daun jagung yang hanya dicelupkan pada pelarut sesuai sediaan. Setelah 48 jam pemaparan, pakan diganti dengan potongan jagung semi tanpa perlakuan. Selain pergantian pakan, setelah 48 jam pemaparan, masing-masing serangga uji dipisahkan dalam wadah plastik satu larva per wadah plastik untuk menghindari kematian serangga uji akibat sifat kanibalisme dari $S$. frugiperda.

Pengamatan dilakukan terhadap mortalitas larva uji sejak hari pertama setelah aplikasi yaitu sejak larva instar II hingga larva yang bertahan hidup berkembang mencapai instar VI, lama perkembangan instar II-VI, konsumsi pakan, dan bobot pupa. Lama perkembangan larva diamati dengan mencatat waktu yang diperlukan larva $S$. frugiperda untuk berkembang dari instar tertentu ke instar berikutnya yang ditandai dengan pergantian kutikula larva. Pengamatan dilakukan setiap hari dengan jangka waktu 24 jam. Pengamatan bobot pupa dilakukan dengan menimbang bobot pupa $S$. frugiperda dengan timbangan analitik. Pengamatan konsumsi pakan dilakukan dengan mengukur luas area yang dimakan oleh larva kemudian disalin di atas kertas milimeter blok. Bagian yang berlubang diarsir dengan menggunakan pensil 2B Kemudian, luas area yang termakan dihitung sebagai persentase menggunakan persamaan:

$$
(\%)=\frac{\Sigma \text { luas daun yang dimakan }}{\Sigma \text { total luas daun }} \times 100 \%
$$

Sifat aktivitas campuran dianalisis dengan menghitung indeks kombinasi (IK) pada taraf LC50 dan LC95 berdasarkan model kerja bersama berbeda (Chou \& Talalayi, 1984):

$$
\mathrm{IK}=\frac{L C x^{1(\mathrm{~cm})}}{L C x^{1}}+\frac{L C x^{2(\mathrm{~cm})}}{L C x^{2}}+\left[\frac{L C x^{1(\mathrm{~cm})}}{L C x^{1}} x \frac{L C x^{2(\mathrm{~cm})}}{L C x^{2}}\right]
$$

$\mathrm{LCx}^{1}$ dan $\mathrm{LCx}^{2}$ masing-masing merupakan LCx minyak $A$. indica dan $R$. communis pada pengujian terpisah; $\mathrm{LCx}^{1(\mathrm{~cm})}$ dan $\mathrm{LCx}^{2(\mathrm{~cm})}$ masingmasing LC komponen $A$. indica dan $R$. communis dalam campuran yang mengakibatkan mortalitas $\mathrm{x}$ (misal 50\% dan 95\%). Nilai LC tersebut diperoleh dengan cara mengalikan LCx campuran dengan proporsi konsentrasi komponen $A$. indica dan $R$. communis. Kategori sifat interaksi campuran adalah sebagai berikut: a. bila IK $<0,5$, komponen campuran bersifat sinergistik kuat; b. bila $0,5 \leq \mathrm{IK} \leq$ 0,77, komponen campuran bersifat sinergistik lemah; c. bila $0,77<\mathrm{IK} \leq 1,43$, komponen campuran bersifat aditif; $d$. bila IK $>1,43$, komponen campuran bersifat antagonistik.

\section{Uji Pengaruh Minyak Nabati terhadap Fekunditas S. frugiperda}

Konsentrasi yang digunakan dalam perlakuan uji fekunditas yaitu LC50 tunggal A. indica, LC50 tunggal $R$. communis, LC25; LC50; dan LC75 A. indica $R$. communis dari hasil uji lanjutan. Selanjutnya perlakuan uji terhadap larva menggunakan prosedur yang sama dengan uji toksisitas yang telah dipaparkan di atas. Jumlah keseluruhan larva yang diberi perlakuan untuk setiap taraf konsentrasi uji dan kontrol diperhitungkan agar saat pengujian tersedia pasangan imago normal dan sehat. Larva uji yang berhasil hidup pada jenjang perkembangan berikutnya dipelihara hingga membentuk pupa dan menjadi imago. Imago sehat yang keluar dari pupa pada setiap perlakuan dan kontrol dipasangkan sebanyak sepuluh ulangan untuk setiap konsentrasi uji.

Setiap pasang dimasukkan ke dalam stoples plastik (diameter $13,5 \mathrm{~cm}$, tinggi $13,5 \mathrm{~cm}$ ) berventilasi kasa yang di dalamnya terdapat tanaman jagung sebagai tempat peletakkan telur. Di dalam kurungan diberi cairan madu $10 \%$ dalam air yang diserapkan pada segumpal kapas, selanjutnya imago dipelihara hingga semua imago mati. Pengamatan dilakukan terhadap jumlah telur yang diletakkan per hari, jumlah telur selama imago betina hidup, jumlah telur yang menetas, jumlah telur yang tersisa dalam ovari, dan lama hidup imago jantan dan betina.

\section{Analisis Data}

Data hubungan konsentrasi dengan mortalitas larva uji dianalisis menggunakan analisis probit program Poloplus 1.0. Data lama perkembangan dan bobot pupa disajikan dalam bentuk nilai rata-rata dan standar deviasi, sedangkan data konsumsi pakan 
dan fekunditas dianalisis dengan analisis sidik ragam. Perbedaan antar perlakuan pada konsumsi pakan dan fekunditas diuji lanjut dengan menggunakan uji jarak berganda Duncan pada taraf 5\% menggunakan program SPSS versi 25.

\section{HASIL DAN PEMBAHASAN}

\section{Toksisitas Tunggal dan Campuran Minyak Nabati}

Larva $S$. frugiperda yang diberi perlakuan minyak nabati tunggal dan campuran menunjukkan mortalitas yang meningkat sejalan dengan konsentrasi yang diberikan (Gambar 1). Larva $S$. frugiperda perlakuan minyak $A$. indica dan campuran minyak $A$. indica $R$. communis pada konsentrasi yang diuji menunjukkan kenaikan mortalitas pada 2 HAS (Hari Setelah Aplikasi) sampai 11 HSA, dan relatif konstan pada 12 HSA. Sementara itu, hasil analisis probit $\mathrm{LC}_{50}$ dan $\mathrm{LC}_{95}$ menunjukkan nilai yang semakin kecil (tingkat toksisitas yang semakin tinggi) dengan bertambahnya waktu pengamatan yang sejalan dengan pola perkembangan mortalitas serangga uji (Tabel 1). Nilai LC50 dan LC95 campuran minyak nabati pada semua pengamatan lebih rendah dibandingkan dengan minyak $R$. communis secara tunggal, sedangkan pada minyak $A$. indica secara tunggal menunjukkan nilai yang mendekati LC50 dan LC95 pada uji campuran minyak. Hasil pengujian menunjukkan minyak $A$. indica, $R$. communis, serta campurannya efektif menyebabkan kematian larva S. frugiperda. Tulashie et al. (2021) melaporkan bahwa perlakuan minyak $A$. indica konsentrasi 3\% mengakibatkan kematian larva $S$. frugiperda $100 \%$ dalam 6 jam. Hasil pengujian Dono dkk. (2020) menunjukkan bahwa perlakuan minyak $R$. communis konsentrasi $0,1 \%$ menyebabkan kematian larva $S$. frugiperda $27,5 \%$.

Minyak $A$. indica diketahui mengandung beberapa senyawa yang salah satunya yaitu azadirakhtin, yang bertindak sebagai antifeedant, penghambat perkembangan, serta gangguan hormonal yang dapat meningkatkan mortalitas pada $D$. melanogaster dan $S$. frugiperda (Bendjazia et al., 2016; Duarte et al., 2019; Dono dkk., 2020). Adapun mortalitas larva $S$. frugiperda pada perlakuan minyak $R$. communis diduga akibat adanya alkaloid berupa risinin. Risinin merangsang sistem syaraf pusat dengan meningkatan transmisi impuls sehingga menyebabkan gangguan berupa tremor, kejangkejang, dan akhirnya kematian (Ferraz et al., 1999).
Pada Tabel 2 disajikan rata-rata persentase konsumsi pakan larva $S$. frugiperda pada perlakuan minyak nabati tunggal dan campuran secara nyata lebih rendah daripada pada perlakuan kontrol, kecuali perlakuan minyak $A$. indica $0,003 \%$ tidak berbeda nyata dengan perlakuan kontrol. Hal tersebut diduga akibat kandungan senyawa pada minyak $A$. indica pada konsentrasi rendah sehingga tidak menimbulkan gangguan secara langsung untuk proses penghentian makan larva $S$. frugiperda. Perlakuan yang menyebabkan konsumsi pakan paling rendah yaitu $R$. communis pada konsentrasi sebesar 1,18\%, yang menunjukkan aktivitas penghambatan makan paling tinggi. Namun, konsumsi pakan pada perlakuan campuran minyak $A$. indica $+R$. communis lebih rendah dari perlakuan $A$. indica saja. Hal tersebut diakibatkan dari efek minyak nabati yang bersifat penghambat makan pada larva yang mengakibatkan berkurangnya konsumsi pakan. Azadirakhtin yang terdapat pada minyak $A$. indica dilaporkan dapat merangsang kerusakan sel dan menghalangi sel fagostimulan yang dapat menyebabkan penghambatan makan, yang berujung pada kelaparan dan kematian (Duarte et al., 2019). Sementara itu, minyak $R$. communis mengandung risinin yang memiliki aktivitas insektisida pada larva $S$. frugiperda (Lopez et al., 2010).

Perlakuan minyak nabati tunggal dan campuran mengakibatkan terhambatnya perkembangan larva sesuai dengan besaran konsentrasi yang diberikan (Tabel 3). Larva $S$. frugiperda pada perlakuan tunggal minyak $A$. indica dan campuran minyak $A$. indica+ $R$. communis menyelesaikan tahap perkembangan larva yang lebih lama 1-6 hari dibandingkan dengan kontrol, sedangkan perlakuan tunggal minyak $R$. communis lebih lama 1-3 hari daripada kontrol. Hal tersebut dipengaruhi oleh senyawa azadirakhtin yang terdapat minyak $A$. indica yang dapat meningkatkan waktu perkembangan larva $S$. frugiperda (Duarte et al., 2019). Sementara itu, hambatan perkembangan pada larva perlakuan minyak $R$. communis dilaporkan akibat adanya inhibitor trypsin yang dapat mengurangi penyerapan asam amino esensial yang tersedia pada $S$. frugiperda (Ramos et al., 2013).

Perubahan morfologi juga terjadi pada perlakuan tunggal minyak $A$. indica dan campuran minyak $A$. indica $+R$. communis pada tahap larva, pre pupa, dan imago. Larva $S$. frugiperda menunjukkan gangguan proses perkembangan larva berupa eksuvia lama yang tidak terlepas sempurna dan menempel di 
tubuh sehingga menyebabkan kematian serangga (Gambar 2a). Sementara itu, pada tahap pre pupa gangguan terjadi berupa pecahnya kutikula lama sepanjang garis tengah dorsal, meso dan metatorak dan diatas pronotum kapsul kepala, tetapi proses yang terjadi tidak berlanjut dan berujung pada kematian pada tahap pre pupa (Gambar 2b). Gangguan perkembangan juga terjadi setelah pupa terbentuk dimana sebagian imago tidak berhasil keluar dari pupa dan hanya berhasil keluar setengah badan (Gambar 2c).
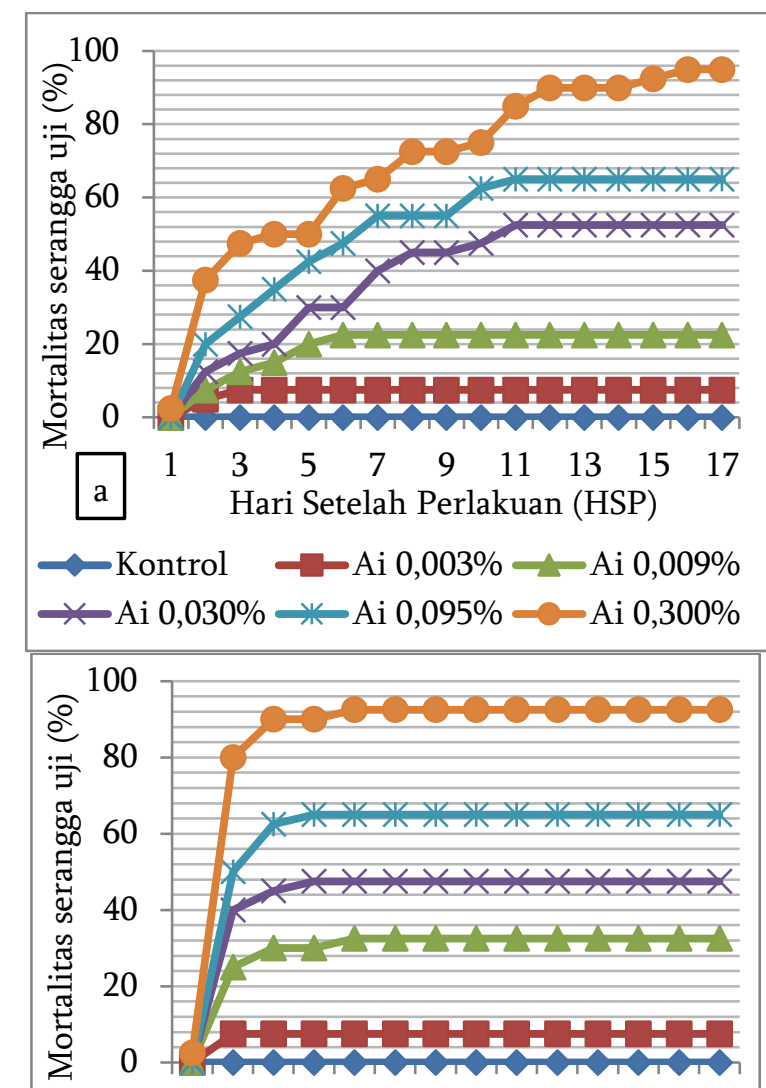

b $\quad \begin{array}{llllllllll}1 & 2 & 3 & 4 & 5 & 6 & 7 & 8 & 9 & 1011121314\end{array}$ Hari Setelah Perlakuan (HSP)

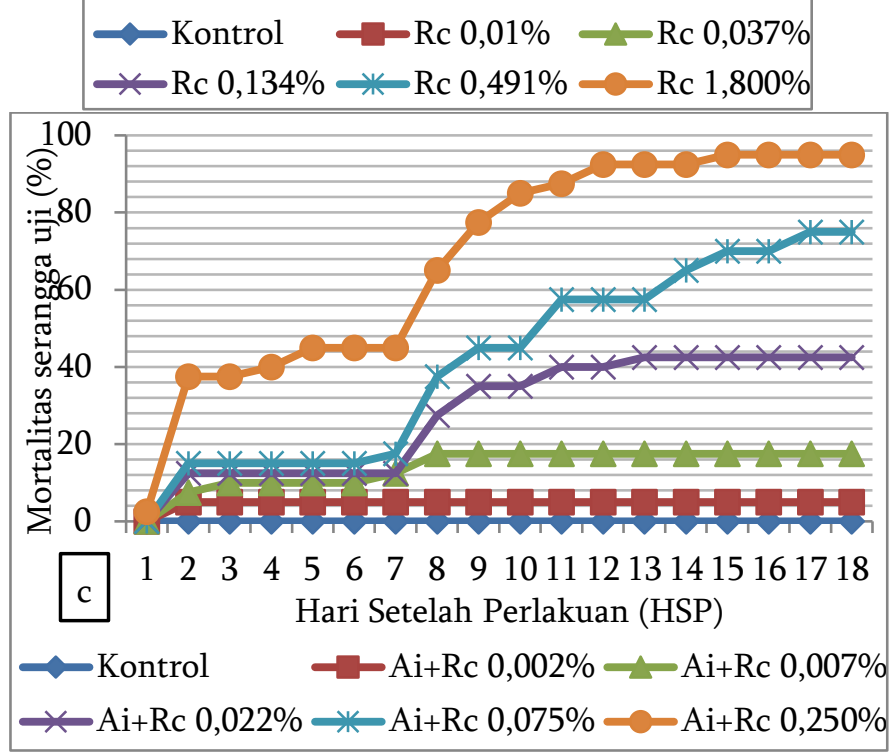

Gambar 1. Mortalitas kumulatif $S$. frugiperda berbagai taraf konsentrasi minyak nabati: a) minyak $A$. indica; b) minyak $R$. communis, c) minyak $A$. indica+ $R$. communis (1:1) 
Tabel 1. Hasil analisis regresi probit toksisitas minyak $A$. indica dan $R$. communis terhadap $S$. frugiperda berdasarkan waktu

\begin{tabular}{|c|c|c|c|c|c|c|c|}
\hline $\begin{array}{c}\text { Jenis } \\
\text { ekstrak }\end{array}$ & $\begin{array}{c}\text { WP } \\
\text { (HSA) }\end{array}$ & $\mathrm{a} \pm \mathrm{SE}$ & $\mathrm{b} \pm \mathrm{SE}$ & LC50(\%) & (SK 95\%) & LC95(\%) & (SK95\%) \\
\hline \multirow{9}{*}{ A. indica } & 2 & $0,064 \pm 0,261$ & $0,808 \pm 0,195$ & 0,833 & $0,310-9,983$ & 90,304 & $8,227-64933,0$ \\
\hline & 4 & $0,441 \pm 0,247$ & $0,829 \pm 0,175$ & 0,293 & $0,146-1,207$ & 28,268 & $4,215-2592,8$ \\
\hline & 6 & $0,843 \pm 0,246$ & $0,925 \pm 0,170$ & 0,123 & $0,053-1,052$ & 7,363 & $0,926-55820,0$ \\
\hline & 8 & $1,247 \pm 0,254$ & $1,079 \pm 0,172$ & 0,070 & $0,027-0,449$ & 2,336 & $0,394-25543,0$ \\
\hline & 10 & $1,443 \pm 0,260$ & $1,166 \pm 0,175$ & 0,058 & $0,022-0,282$ & 1,490 & $0,297-4668,9$ \\
\hline & 12 & $2,064 \pm 0,294$ & $1,498 \pm 0,192$ & 0,042 & $0,019-0,107$ & 0,525 & $0,169-24,073$ \\
\hline & 14 & $2,064 \pm 0,294$ & $1,498 \pm 0,192$ & 0,042 & 0,019-0,107 & 0,525 & $0,169-24,073$ \\
\hline & 16 & $2,315 \pm 0,315$ & $1,643 \pm 0,203$ & 0,039 & $0,017-0,100$ & 0,391 & $0,134-16,671$ \\
\hline & 18 & $2,315 \pm 0,315$ & $1,643 \pm 0,203$ & 0,039 & $0,017-0,100$ & 0,391 & $0,134-16,671$ \\
\hline \multirow{9}{*}{$\begin{array}{c}R . \\
\text { communis }\end{array}$} & 2 & $0,484 \pm 0,141$ & $0,902 \pm 0,134$ & 0,291 & $0,178-0,523$ & 19,352 & $6,140-146,093$ \\
\hline & 4 & $0,878 \pm 0,156$ & $1,087 \pm 0,142$ & 0,156 & $0,102-0,241$ & 5,084 & $2,246-18,943$ \\
\hline & 6 & $0,933 \pm 0,159$ & $1,109 \pm 0,143$ & 0,144 & $0,094-0,221$ & 4,379 & $1,986-15,516$ \\
\hline & 8 & $0,933 \pm 0,159$ & $1,109 \pm 0,143$ & 0,144 & $0,094-0,221$ & 4,379 & $1,986-15,516$ \\
\hline & 10 & $0,933 \pm 0,159$ & $1,109 \pm 0,143$ & 0,144 & $0,094-0,221$ & 4,379 & $1,986-15,516$ \\
\hline & 12 & $0,933 \pm 0,159$ & $1,109 \pm 0,143$ & 0,144 & $0,094-0,221$ & 4,379 & $1,986-15,516$ \\
\hline & 14 & $0,933 \pm 0,159$ & $1,109 \pm 0,143$ & 0,144 & $0,094-0,221$ & 4,379 & $1,986-15,516$ \\
\hline & 16 & $0,933 \pm 0,159$ & $1,109 \pm 0,143$ & 0,144 & $0,094-0,221$ & 4,379 & $1,986-15,516$ \\
\hline & 18 & $0,933 \pm 0,159$ & $1,109 \pm 0,143$ & 0,144 & $0,094-0,221$ & 4,379 & $1,986-15,516$ \\
\hline \multirow{9}{*}{$\begin{array}{c}\text { A. indica+ } R \text {. } \\
\text { communis } \\
\quad(1: 1)\end{array}$} & 2 & $0,093 \pm 0,285$ & $0,817 \pm 0,205$ & 0,769 & $0,275-11,576$ & 79,147 & $6,7747-88241,0$ \\
\hline & 4 & $0,122 \pm 0,282$ & $0,804 \pm 0,199$ & 0,705 & $0,256-9,844$ & 78,314 & $6,710-83412,0$ \\
\hline & 6 & $0,277 \pm 0,280$ & $0,893 \pm 0,198$ & 0,489 & $0,212-3,261$ & 34,001 & $4,470-5439,2$ \\
\hline & 8 & $1,001 \pm 0,272$ & $1,074-0,184$ & 0,117 & $0,052-1,024$ & 3,972 & $0,612-11249,0$ \\
\hline & 10 & $1,765 \pm 0,297$ & $1,453 \pm 0,196$ & 0,061 & $0,028-0,263$ & 0,826 & $0,214-230,373$ \\
\hline & 12 & $2,345 \pm 0,331$ & $1,729 \pm 0,212$ & 0,044 & $0,023-0,113$ & 0,394 & $0,140-10,893$ \\
\hline & 14 & $2,523 \pm 0,343$ & $1,801 \pm 0,217$ & 0,040 & $0,022-0,086$ & 0,325 & $0,129-4,357$ \\
\hline & 16 & $2,831 \pm 0,371$ & $1,964 \pm 0,231$ & 0,036 & $0,022-0,069$ & 0,249 & $0,111-1,855$ \\
\hline & 18 & $2,991 \pm 0,385$ & $2,041 \pm 0,238$ & 0,034 & $0.134-6.671$ & 0,219 & $0,104-1,251$ \\
\hline
\end{tabular}

Keterangan: WP: waktu pengamatan; HSA: hari setelah aplikasi; a: intersep garis regresi probit ; b: kemiringan garis regresi probit; SE: standar error; SK: selang kepercayaan; LC: lethal concentration

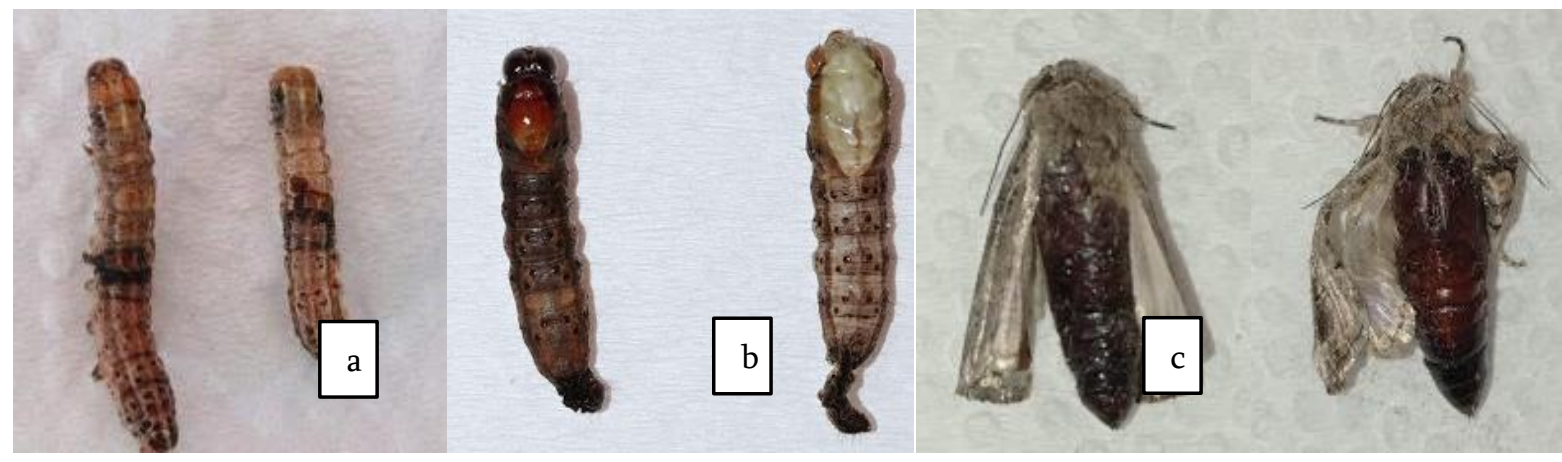

Gambar 2. Pengaruh minyak nabati terhadap perkembangan $S$. frugiperda: a) larva gagal ganti kutikula perlakuan minyak $A$. indica dan campuran minyak $A$. indica+ $R$. communis, b) larva gagal membentuk pupa perlakuan campuran minyak $A$. indica+ $R$. communis; c) imago tidak berhasil keluar dari pupa perlakuan campuran minyak $A$. indica+ $R$. communis 
Tabel 2. Pengaruh minyak nabati terhadap konsumsi pakan larva $S$. frugiperda pada 2HSA

\begin{tabular}{ccc}
\hline Perlakuan & Konsentrasi $(\%)$ & Rata-rata konsumsi pakan larva $S$. frugiperda $(\boldsymbol{x} \pm \mathrm{SD})(\%)$ \\
\hline \multirow{3}{*}{ A. indica } & 0,003 & $38,59 \pm 7,69 \mathrm{de}$ \\
& 0,009 & $31,66 \pm 7,48 \mathrm{~cd}$ \\
& 0,030 & $30,14 \pm 9,32 \mathrm{~cd}$ \\
& 0,095 & $28,38 \pm 10,90 \mathrm{bc}$ \\
R. communis & 0,300 & $9,60 \pm 4,42 \mathrm{a}$ \\
\hline & 0,010 & $6,06 \pm 3,09 \mathrm{a}$ \\
& 0,037 & $5,30 \pm 0,98 \mathrm{a}$ \\
A. indica+R. communis & 0,134 & $4,77 \pm 1,40 \mathrm{a}$ \\
$(1: 1)$ & 0,491 & $2,77 \pm 0,51 \mathrm{a}$ \\
& 1,800 & $1,18 \pm 0,41 \mathrm{a}$ \\
\hline Kontrol & 0,002 & $23,05 \pm 11,15 \mathrm{bc}$ \\
& 0,007 & $19,21 \pm 8,27 \mathrm{~b}$ \\
& 0,022 & $7,68 \pm 2,41 \mathrm{a}$ \\
\hline
\end{tabular}

Keterangan: Nilai rata-rata yang diikuti huruf yang sama tidak berbeda nyata (uji Duncan, $\alpha=0,05$ )

Tabel 3. Pengaruh konsentrasi minyak $A$. indica dan $R$. communis tunggal serta campuran terhadap lama perkembangan larva $S$. frugiperda instar II sampai VI

\begin{tabular}{|c|c|c|c|c|c|c|c|c|c|}
\hline \multirow{2}{*}{ Perlakuan } & \multicolumn{9}{|c|}{ Rata-rata lama perkembangan larva \pm SD (hari) } \\
\hline & Konsentrasi (\%) & Instar II-III & $\mathrm{n}$ & Instar II-IV & $\mathrm{n}$ & Instar II-V & $\mathrm{n}$ & Instar II-VI & $\mathrm{n}$ \\
\hline \multirow{5}{*}{ A. indica } & 0,003 & $2,18 \pm 0,393$ & 38 & $4,41 \pm 0,498$ & 37 & $6,84 \pm 0,374$ & 37 & $10,43 \pm 0,765$ & 37 \\
\hline & 0,009 & $2,51 \pm 0,507$ & 37 & $4,75 \pm 0,508$ & 32 & $7,29 \pm 0,461$ & 31 & $11,29 \pm 0,529$ & 31 \\
\hline & 0,030 & $2,88 \pm 0,331$ & 33 & $6,39 \pm 0,737$ & 28 & $10,68 \pm 0,477$ & 22 & $13,79 \pm 0,535$ & 19 \\
\hline & 0,095 & $2,93 \pm 0,258$ & 29 & $6,43 \pm 0,728$ & 23 & $10,79 \pm 0,699$ & 14 & $14,21 \pm 0,579$ & 14 \\
\hline & 0,300 & $3,10 \pm 0,308$ & 20 & $7,13 \pm 0,915$ & 15 & $12,50 \pm 1,000$ & 4 & $16,50 \pm 0,707$ & 2 \\
\hline \multirow{5}{*}{$\begin{array}{c}R . \\
\text { communis }\end{array}$} & 0,010 & $2,13 \pm 0,343$ & 38 & $5 \pm 0,471$ & 37 & $7,27 \pm 0,608$ & 37 & $11,03 \pm 0,600$ & 37 \\
\hline & 0,037 & $2,07 \pm 0,258$ & 29 & $5,04 \pm 0,576$ & 28 & $7,67 \pm 0,480$ & 27 & $11,63 \pm 0,565$ & 27 \\
\hline & 0,134 & $2,13 \pm 0,338$ & 24 & $5,14 \pm 0,359$ & 21 & $8,14 \pm 0,359$ & 21 & $12,24 \pm 0,436$ & 21 \\
\hline & 0,491 & $2,40 \pm 0,503$ & 20 & $5,93 \pm 0,829$ & 14 & $9 \pm 0,784$ & 14 & $13,07 \pm 0,730$ & 14 \\
\hline & 1,800 & $2,63 \pm 0,518$ & 8 & $6 \pm 1,000$ & 3 & $9 \pm 1,000$ & 3 & $13,67 \pm 0,577$ & 3 \\
\hline \multirow{5}{*}{$\begin{array}{c}\text { A. indica }+R \text {. } \\
\text { communis } \\
(1: 1)\end{array}$} & 0,002 & $2,11 \pm 0,311$ & 38 & $5,16 \pm 0,370$ & 38 & $8,00 \pm 0,569$ & 38 & $11,68 \pm 0,873$ & 38 \\
\hline & 0,007 & $2,76 \pm 0,435$ & 37 & $5,77 \pm 0,426$ & 35 & $8,76 \pm 0,435$ & 33 & $12,36 \pm 0,783$ & 33 \\
\hline & 0,022 & $2,80 \pm 0,406$ & 35 & $6,49 \pm 0,507$ & 35 & $9,44 \pm 0,506$ & 27 & $14,17 \pm 0,887$ & 23 \\
\hline & 0,075 & $3,15 \pm 0,359$ & 34 & $6,56 \pm 0,504$ & 34 & $10,32 \pm 0,995$ & 22 & $15,10 \pm 0,738$ & 10 \\
\hline & 0,250 & $3,40 \pm 0,500$ & 25 & $7,89 \pm 0,900$ & 18 & $13,50 \pm 0,707$ & 2 & $16,50 \pm 0,707$ & 2 \\
\hline Kontrol & 0 & $2,13 \pm 0,335$ & 40 & $4,13 \pm 0,335$ & 40 & $6,38 \pm 0,490$ & 40 & $10,05 \pm 0,221$ & 40 \\
\hline
\end{tabular}

Azadirakhtin memengaruhi sistem neurosecretory pada serangga dengan menghalangi pelepasan hormon morfogenetik peptida seperti hormon protorasikotoprik (PTTH) dan allatostatin, yang selanjutnya mengontrol corpora allata untuk mensekresi hormon juvenil, dan menghambat sintesis hormon ekdisteroid sehingga mengakibatkan keterlambatan dan kelainan proses pergantian kutikula (Mordue \& Nisbet, 2000). Sejalan dengan yang dilaporkan Duarte et al. (2019) bahwa efek 
azadirakhtin yang terdapat pada minyak $A$. indica menyebabkan gangguan hormonal pada $S$. frugiperda yang berpengaruh pada proses metamorfosis.

Tabel 4. Pengaruh minyak $A$. indica dan $R$. communis tunggal dan campuran terhadap bobot pupa

\begin{tabular}{cccc}
\hline Perlakuan & $\begin{array}{c}\text { Konsentrasi } \\
(\%)\end{array}$ & $\mathrm{n}$ & $\begin{array}{c}\text { Bobot pupa } \pm \text { SD } \\
(\mathrm{gram})\end{array}$ \\
\hline & 0,003 & 37 & $0,1817 \pm 0,0052$ \\
A. indica & 0,009 & 31 & $0,1933 \pm 0,0068$ \\
& 0,030 & 19 & $0,1870 \pm 0,0091$ \\
& 0,095 & 14 & $0,1602 \pm 0,0177$ \\
& 0,300 & 2 & $0,1195 \pm 0,0069$ \\
\hline . communis & 0,010 & 37 & $0,1867 \pm 0.0065$ \\
& 0,037 & 27 & $0,1871 \pm 0,0016$ \\
& 0,491 & 14 & $0,1816 \pm 0,0089$ \\
& 1,800 & 3 & $0,1866 \pm 0,0139$ \\
\hline comdica+R. & 0,007 & 30 & $0,1808 \pm 0,0037$ \\
(1:1) & 0,002 & 38 & $0,1739 \pm 0,0047$ \\
& 0,075 & 7 & $0,1714 \pm 0,0060$ \\
\hline Kontrol & 0,250 & 2 & $0,1547 \pm 0,0077$ \\
\hline Keterangan: n: jumlah pupa & & $0,1920 \pm 0,0051$ \\
& 0 & 40 & $0,1802 \pm 0,0078$ \\
\hline
\end{tabular}

Rendahnya bobot pupa pada perlakuan tunggal minyak $A$. indica dan campuran $A$. indica+R. communis yang ditunjukkan pada tabel 4 diduga akibat aktivitas antifeedant dari minyak $A$. indica seperti yang dibahas sebelumnya, setelah mencapai tahap akhir larva, $S$. frugiperda mempersiapkan metamorfosis selanjutnya. Namun, pemanfaatan nutrisi yang tidak optimal dari makanan yang dicerna menyebabkan bobot pupa yang rendah.

\section{Sifat Aktivitas Campuran Minyak Nabati}

Indeks kombinasi (IK) campuran minyak $A$. indica dan $R$. communis pada pengamatan 2 HSA sampai 8 HSA LC $_{50}$ bersifat antagonistik, pada pengamatan $10 \mathrm{HSA} \mathrm{LC}_{50}$ bersifat aditif, sedangkan pada pengamatan 12 sampai 18 HSA LC50 bersifat sinergistik lemah. Pengamatan 2 sampai 8 HSA taraf LC95 bersifat antagonistik, dan pengamatan 10 sampai 18 HSA bersifat sinergistik kuat (Tabel 5).Sifat interaksi campuran minyak $A$. indica+R.communis pada $\mathrm{LC}_{50}$ dan $\mathrm{LC}_{95}$ terjadi perubahan sifat sinergistik yang sejalan dengan waktu pemaparan dan konsentrasi yang digunakan. Hal tersebut sesuai dengan pemaparan sebelumnya bahwa perubahan sifat aktivitas campuran dipengaruhi beberapa faktor diantaranya konsentrasi yang digunakan, lamanya waktu pemaparan, dan cara kerja bahan aktif insektisida pada bagian sasaran.

Azadirakhtin merupakan komponen utama yang terkandung pada minyak $A$. indica (Elteraifi dan Hassanali, 2011). Azadirakhtin dilaporkan memiliki aktivitas utama menggangguan sistem hormonal sehingga dapat mengakibatkan gangguan perkembangan serangga (Kauser et al., 1988; Koul, 1996; Bendjazia et al., 2016). Selain itu, azadirakhtin dilaporkan juga menghambat aktivitas acetylcholinesterase (AChE) (Nathan et al., 2008). Asetilkolin merupakan poplipeptida yang berfungsi sebagai neurotransmitter pada proses penghantaran impuls pada sistem syaraf serangga (Colovic et al., 2013)

Tabel 5. Sifat aktivitas campuran $A$. Indica $+R$. communis (1:1) terhadap larva $S$. Frugiperda

\begin{tabular}{cccccc}
\hline \multirow{2}{*}{ Perlakuan } & \multirow{2}{*}{ WP (HSA) } & \multicolumn{2}{c}{ Indeks kombinasi } & \multicolumn{2}{c}{ Sifat interaksi } \\
\cline { 2 - 5 } & 2 & LC50(\%) & LC95(\%) & LC50(\%) & LC95(\%) \\
\hline & 4 & 2,39 & 3,38 & Antagonistik & Antagonistik \\
& 6 & 5,72 & 19,76 & Antagonistik & Antagonistik \\
A. indica+ $R$ communis $(1: 1)$ & 8 & 4,57 & 15,16 & Antagonistik & Antagonistik \\
& 10 & 1,58 & 1,69 & Antagonistik & Antagonistik \\
& 12 & 0,85 & 0,44 & Aditif & Sinergistik kuat \\
& 14 & 0,74 & 0,44 & Sinergistik lemah & Sinergistik kuat \\
& 16 & 0,66 & 0,36 & Sinergistik lemah & Sinergistik kuat \\
& 18 & 0,63 & 0,36 & Sinergistik lemah & Sinergistik kuat \\
& 0,61 & 0,31 & Sinergistik lemah & Sinergistik kuat \\
\hline
\end{tabular}


Senyawa risin pada minyak $R$. communis berperan sebagai Ribosome Inactivating Protein (RIP), yang bekerja menonaktifkan ribosom dan menghentikan sintesis protein (Maheshwari \& Kovalchuk, 2016), serta bersifat toksik terhadap sistem syaraf pusat sehingga menyebabkan kematian serangga (Stirpe \& Oriol, 2016). Sifat aktivitas sinergistik campuran minyak biji $A$. indica+ $R$. communis merupakan pengaruh kerja bersama senyawa aktif yang terkandung dalam campuran kedua jenis minyak pada bagian sasaran.

Pengaruh Minyak Nabati terhadap Fekunditas $S$. frugiperda

Pada pengamatan masa pre oviposisi, masa oviposisi, dan telur yang tersisa dalam ovari, uji jarak berganda Duncan tidak dilakukan karena tidak memenuhi syarat untuk uji lanjut (Tabel 6). Jumlah keseluruhan telur yang dihasilkan oleh imago betina $S$. frugiperda pada perlakuan kontrol secara nyata lebih tinggi daripada perlakuan campuran LC25, LC50, dan $\mathrm{LC}_{75}$ minyak $A$. indica+ $R$. communis. Namun, data pada kontrol tidak berbeda nyata dengan data pada perlakuan $\mathrm{LC}_{50} A$. indica dan LC50 $R$. communis tunggal.

Persentase fertilitas imago betina $S$. frugiperda pada perlakuan kontrol secara nyata lebih tinggi daripada LC75 campuran minyak $A$. indica+ $R$. communis, tetapi tidak berbeda nyata dengan keempat jenis perlakuan minyak nabati lainnya. Pada parameter lama hidup imago jantan dan imago betina, perlakuan kontrol secara nyata lebih lama daripada kelima jenis perlakuan tunggal dan campuran minyak nabati. Perlakuan minyak $A$. indica dan $R$. communis serta campurannya meningkatkan jumlah telur matang yang tersisa dalam ovari setelah imago betina mati (Tabel 6).

Gangguan reproduksi yang terjadi diduga akibat aktivitas senyawa yang terdapat pada minyak $A$. indica dan $R$. communis, yang bekerja secara tunggal maupun campuran. Efek toksik dari azadirakhtin yang menghambat oogenesis dan produksi ekdisteroid sehingga mengakibatkan terganggunya fekunditas dan fertilitas telur pada Diatraea saccharalis (Schneider et al., 2017). Selain itu, Duarte et al. (2019) melaporkan bahwa efek dari perlakuan minyak $A$. indica selama periode larva menyebabkan kesulitan dalam mengasimilasi nutrisi sehingga jumlah telur yang dihasilkan berkurang, serta mengakibatkan penurunan lama hidup imago jantan dan betina. Selanjutnya Bell \& Bohm (1975) melaporkan bahwa serangga akan melakukan strategi reproduksi untuk menjamin keberhasilan reproduksi, dimana oosit yang sedang berkembang diserap dalam ovarium sebagai respon faktor internal. Sementara itu, penurunan lama hidup imago jantan dan betina yang singkat pada semua perlakuan minyak nabati akan berdampak di lapangan yang dapat mengurangi waktu untuk mencari pasangan dan waktu betina harus bertelur (Duarte et al., 2019). Dengan demikian, gangguan yang terjadi pada $S$. frugiperda seperti hambatan makan, perkembangan, dan pertumbuhan, serta reproduksi menyebabkan berkurangnya populasi dan mencegah merusak tanaman.

Tabel 6. Pengaruh minyak $A$. indica dan $R$. communis terhadap fekunditas $S$. frugiperda

\begin{tabular}{|c|c|c|c|c|c|c|c|}
\hline \multirow{2}{*}{ Perlakuan } & \multirow{2}{*}{$\begin{array}{c}\text { Masa pre } \\
\text { oviposisi (hari) }\end{array}$} & \multirow{2}{*}{$\begin{array}{c}\text { Masa oviposisi } \\
\text { (hari) }\end{array}$} & \multirow{2}{*}{$\begin{array}{c}\sum \text { Telur/ betina } \\
\text { (butir) }\end{array}$} & \multirow{2}{*}{$\begin{array}{c}\text { Fertilitas } \\
(\%)\end{array}$} & \multirow{2}{*}{$\begin{array}{c}\sum \text { Telur } \\
\text { tersisa (butir) }\end{array}$} & \multicolumn{2}{|c|}{ Lama hidup imago (hari) } \\
\hline & & & & & & Jantan & Betina \\
\hline LC50Ai & $3,5 \pm 1,2$ & $6,9 \pm 2,9$ & $668,2 \pm 519,3 \mathrm{ab}$ & $94,1 \pm 40,2 \mathrm{~b}$ & $39,3 \pm 79,0$ & $11,9 \pm 2,9 \mathrm{a}$ & $10,1 \pm 3,2 \mathrm{a}$ \\
\hline LC 50 Rc & 4,0 & $5,6 \pm 2,5$ & $522,9 \pm 272,9 \mathrm{ab}$ & $80,8 \pm$ & 29,4 & $\pm 4,4$ a & $1,9 \mathrm{a}$ \\
\hline $\mathrm{LC} 25 \mathrm{Ai}+\mathrm{Rc}$ & $4,0 \pm 1,9$ & $5,1 \pm$ & $429,3 \pm 202,6 \mathrm{a}$ & $77,8 \pm 29,6 \mathrm{ab}$ & $2,70 \pm$ & $13,2 \pm 4,8 \mathrm{a}$ & $3,2 \mathrm{a}$ \\
\hline $\mathrm{LC}{ }_{50} \mathrm{Ai}+\mathrm{Rc}$ & $4,6 \pm 2,2$ & $4,6 \pm 3,0$ & $409,0 \pm 289,7 \mathrm{a}$ & $78,2 \pm 42,6 \mathrm{ab}$ & $5,30 \pm 12,0$ & $11,8 \pm 4,4 \mathrm{a}$ & $8,6 \pm 4,8 \mathrm{a}$ \\
\hline $\mathrm{LC} 75 \mathrm{Ai}+\mathrm{Rc}$ & $4,0 \pm 1,1$ & $5,1 \pm 2,9$ & $431,1 \pm 303,9 \mathrm{a}$ & $61,4 \pm 30,2 \mathrm{a}$ & $28,0 \pm 83,4$ & $9,60 \pm 4,2 \mathrm{a}$ & $9,8 \pm 2,9$ a \\
\hline Kontrol & $3,1 \pm 0,6$ & $7,9 \pm 2,3$ & $819,3 \pm 325,3 b$ & $98,6 \pm 2,30 \mathrm{~b}$ & 0 & $19,7 \pm 2,6 \mathrm{~b}$ & $13,4 \pm 2,9 \mathrm{~b}$ \\
\hline
\end{tabular}

Keterangan: Nilai rata-rata dalam satu kolom yang diikuti oleh huruf kecil yang sama, tidak berbeda nyata (ANOVA, dilanjutkan uji Duncan pada $\alpha=0,05$ )

\section{SIMPULAN}

Minyak $A$. indica, $R$. communis, serta campurannya bersifat toksik terhadap larva $S$. frugiperda degan nilai LC95 pada 18 hari setelah aplikasi (HSA) berturut-turut yaitu 0,391\%, 4,379\%, dan 0,219\%. Aktivitas campuran minyak $A$. indica dan $R$. communis pada taraf LC50 waktu pengamatan 12-18 HSA bersifat sinergistik lemah, sementara pada taraf LC95 waktu pengamatan 10-18 HSA bersifat sinergistik kuat. Selain itu, minyak nabati tersebut memiliki aktivitas penghambatan 
perkembangan, penurunan fekunditas dan fertilitas, serta penurunan umur imago jantan dan betina $S$. frugiperda. Dengan demikian, campuran minyak nabati $A$. indica dan $R$. communis berpotensi dikembangkan sebagai insektisida alternatif pengendalian $S$. frugiperda.

\section{UCAPAN TERIMA KASIH}

Penelitian ini merupakan bagian dari penelitian yang berjudul Formulasi Insektisida Botani Ekstrak Biji Azadirachta indica: Peningkatan Bioaktivitas Berbasis Kombinasi Campuran Bahan Nabati dengan peneliti utama Dr. Danar Dono, M.Si. yang dibiayai melalui Hibah Internal Universitas Padjadjaran dengan skema hibah Riset Disertasi Doktor Unpad Tahun 2019-2021. Kepada Rektor Universitas Padjadjaran disampaikan terima kasih.

\section{DAFTAR PUSTAKA}

Alves, APC, AD Corrêa, DS Alves, AA Saczk, JBR Lino, and GA Carvalho. 2014. Toxicity of the phenolic extract from jabuticabeira (Myrciaria cauliflora (Mart.) O. Berg) fruit skins on Spodoptera frugiperda. Chilean Journal of Agricultural Research. 74(2): 200204.

Bell, BYWJ, and MK Bohm. 1975. Oosorption in insects. Biological Reviews of the Cambridge Philosophical Society. 50(4): 373-396.

Bendjazia, RB, SK Morakchi, and N Aribi. 2016. Growth and molting disruption effects of azadirachtin against Drosophila melanogaster (Diptera: Drosophilidae). Journal of Entomology and Zoology Studies. 4(1): 363368.

Boaventura, D, M Martin, A Pozzebon, D MotaSanchez, and R Nauen. 2020. Monitoring of target-site mutations conferring insecticide resistance in Spodoptera frugiperda. Insects. 11(8): 1-15.

Chou, T, and P Talalayi. 1984. Quantitative doseeffect relationships: the combined effects of multiple. Advances in Enzyme Regulation. 22: 27-55.

Colovic, MB, DZ Krstic, TD Lazarevic-Pasti, AM Bondzic, and VM Vasic. 2013. Acetylcholinesterase inhibitors: Pharmacology and toxicology. Current Neuropharmacology. 11(3): 315-335.

Dono, D, Y Hidayat, T Suganda, S Hidayat, and N
Widayani. 2020. The toxicity of neem (Azadirachta indica), citronella (Cymbopogon nardus), castor (Ricinus communis), and clove (Syzygium aromaticum) oil against Spodoptera frugiperda. Jurnal Cropsaver. 3(1): 22-30.

Duarte, JP, LR Redaelli, SM Jahnke, and S Trapp. 2019. Effect of Azadirachta indica (Sapindales: Meliaceae) oil on Spodoptera frugiperda (Lepidoptera: Noctuidae) larvae and adults. Florida Entomologist. 102(2): 408412.

Elteraifi, IE, and A Hassanali. 2011. Oil and Azadirachtin contents of neem (Azadirachta indica A. Juss) seed. kernels collected from trees growing in different habitats in Sudan. International Journal of Biological and Chemical Sciences. 5(3): 1063-1072.

FAO. 2018. Integrated Management of the Fall Armyworm on Maize. Rome-Italy. 140pp.

Ferraz, AC, MEM Angelucci, ML Da Costa, IR Batista, BH De Oliveira, and C Da Cunha. 1999. Pharmacological evaluation of ricinine, a central Nervous system stimulant isolated from Ricinus communis. Pharmacology Biochemistry and Behavior. 63(3): 367-375.

Goergen, G, PL Kumar, SB Sankung, A Togola, and $\mathrm{M}$ Tamò. 2016. First report of outbreaks of the fall armyworm Spodoptera frugiperda (J E Smith) (Lepidoptera, Noctuidae), a new alien invasive pest in West and Central Africa. Plos One. 11(10): 1-9.

Kauser, G, HM Brandtner, HJ Bidmon, and J Koolman. 1988. Ecdysone synthesis and release by the brain-ring gland complex of blowfly larvae. Journal of Insect Physiology. 34(7): 563-569.

Koul, O. 1996. Mode of action of azadirachtin in insect. In Neem. NS Raamdhawa and BS Parmar (Eds.). New Age International LTD. New Delhi. pp. 160-170.

Lopez, MR, S Perez, G Rodríguez-Hernandez, P Guevara-Fefer, and M Zavala-Sanchez. 2010. Activity of Ricinus communis (Euphorbiaceae against Spodoptera frugiperda (Lepidoptera : Noctuidae). African Journal of Biotechnology. 9(9): 1359-1365.

Maharani, Y, VK Dewi, LT Puspasari, L Rizkie, Y Hidayat, and D Dono. 2019. Cases of fall army worm Spodoptera frugiperda J. E. Smith (Lepidoptera: Noctuidae) attack on maize in Bandung, Garut and Sumedang District, West 
Java. Jurnal Cropsaver, 2(1), 38.

Maheshwari, P, and I Kovalchuk. 2016. Genetic transformation of crops for oil production. Industrial Oil Crops. 379-412.

Mordue, AJ, and AJ Nisbet. 2000. Azadirachtin from the neem tree Azadirachta indica : its action against insects. Anais da Sociedade Entomologica do Brasil. 29(4): 615-632.

Nathan, SS, MY Choi, HY Seo, CH Paik, K Kalaivani, and JD Kim. 2008. Effect of azadirachtin on acetylcholinesterase (AChE) activity and histology of the brown planthopper Nilaparvata lugens (Stål). Ecotoxicology and Environmental Safety. 70(2): 244-250.

Nuryanti, NSP, E Martono, ES Ratna, and Dadang. 2018. The bioactivities of selected piperaceae and asteraceae plant extracts against brown plant hopper (Nilaparvata lugens stål.). Journal of the International Society for Southeast Asian Agricultural Sciences, 24(2), 70-78.

Ramos, V, D Alves, M Braga, G Carvalho, and C Santos. 2013. Extraction and isolation of antitryptic castor-bean (Ricinus communis L.) substances and their effects on Spodoptera frugiperda (Smith, 1797) (Lepidoptera: Noctuidae). Chilean Journal of Agricultural Research. 73(2), 128-134.

Russianzi, W, and D Prijono. 2019. Synergistic activity of mixtures of Piper aduncum fruit extract and three microorganism-derived insecticides against the Diamond Back Moth, Plutella xylostella. Journal Cropsaver. 2(1): 712.

Rwomushana, I, M Bateman, T Beale, P Beseh, K Cameron, M Chiluba, V Clottey, T Davis, R
Day, and J Tambo. 2018. Fall armyworm: impacts and implications for Africa: Evidence note update. Technical Report. Centre for Agricultural Bioscience International.

Schneider, LCL, CV Silva, and H Conte. 2017. Toxic effect of commercial formulations of neem oil, Azadirachta indica A. Juss., in pupae and adults of the sugarcane borer, Diatraea saccharalis F. (Lepidoptera: Crambidae). Arquivos Do Instituto Biológico. 84: 1-8.

Sisay, B, J Simiyu, E Mendesil, P Likhayo, G Ayalew, S Mohamed, S Subramanian, and T Tefera. 2019. Fall armyworm, Spodoptera frugiperda infestations in East Africa: Assessment of damage and parasitism. Insects. 10(7): 1-10.

Stirpe, F, and RG Oriol. 2016. RibosomeInactivating Proteins: An Overview. Springer.

Susanto, MS, dan D Prijono. 2015. Sinergisme ekstrak Piper aduncum dan Tephrosia vogelii terhadap penggerek batang padi kuning, Scirpophaga incertulas. Agrikultura. 26(1): 714.

Trisyono, YA, S Suputa, VEF Aryuwandari, M Hartaman, and J Jumari. 2019. Occurrence of heavy infestation by the fall armyworm Spodoptera frugiperda, a new alien invasive pest, in corn Lampung Indonesia. Jurnal Perlindungan Tanaman Indonesia. 23(1): 156-160.

Tulashie, SK, F Adjei, J Abraham, and E Addo. 2021. Potential of neem extracts as natural insecticide against fall armyworm (Spodoptera frugiperda (J. E. Smith) (Lepidoptera: Noctuidae). Case Studies in Chemical and Environmental Engineering. 4: 100-130. 